\title{
Gambaran Tingkat Stress Kerja Perawat Ruang Rawat Inap Instalasi Penyakit Dalam RSUP M DJAMIL PADANG
}

\author{
Indri Ramadini ${ }^{1}$, Rika Syafitri ${ }^{2}$ \\ 1. STIKes YPAK Padang \\ 2. STIKes YPAK \\ E-mail:1.indri.ramadini@gmail.com \\ 2.Rika_syafitri28@yahoo.co.id
}

\begin{abstract}
Abstrak
Tenaga keperawatan merupakan ujung tombak dalam memberikan pelayanan di rumah sakit karena perawat adalah provider yang selalu kontak selama 24 jam dengan pasien peran perawat dalam memberikan pelayanan sering mengalami tekanan psikologi, hal ini bisa disebabkan karena beban kerja yang berlebihan, waktu pelaksanaan, kontak penyakit pasien secara langsung kondisi tekanan psikologi seperti ini sering menimbulkan stres (NIOSH, 2008).Stres kerja merupakan suatu kondisi fisik dan emosional yang berbahaya yang terjadi ketika pekerjaan yang dilakukan tidak sesuai dengan kemampuan, sumber daya dan kebutuhan pekerja (NIOSH, 2008). Survey nasional di Perancis (Frasser, 1997), ditemukan bahwa 74\% perawat mengalami stress kerja. Hasil penelitian Persatuan Perawatan Nasional Indonesia (2006) ditemukan 50,9\% perawat Indonesia mengalami stres kerja, yang disebabkan beban kerja terlalu tinggi dan menyita waktu, gaji rendah dan insentif yang tidak memadai (Muthmainah, 2012). Jenis penelitian deskriptif dengan pendekatan cross sectional study, jumlah sampel 20 responden ruang rawat inap. Teknik pengambilan sampel purposive sampling. Data diperoleh dari hasil kuesioner Self report measure dan analisa secara univariat dengan distribusi frekuensi Hasil penelitian menunjukkan sebagian besar perawat (55\%) mengalami stres kerja. Dari hasil dapat disimpulkan adanya stres kerja dilingkungan kerja perawat di ruang rawat inap, diharapkan perawat dapat melakukan cara yang asertif dalam menyelesaikan masalah dan juga pihak rumah sakit menyediakan media konseling bagi perawat yang mengalami stres kerja.
\end{abstract}

Kata Kunci: ;Perawat; Rumah Sakit; Ruang Rawat Inap; Stres Kerja

Overview of Stress Work Levels of Nurse in Inpatient Ward of Internist Installation in RSUP M DJAMIL PADANG

Abstract

Nursing staff is the spearhead in providing services in hospitals because nurses are providers who always contact for 24 hours with patients The role of nurses in providing services often experiences psychological stress, this can be caused by excessive workload, time of execution, patient contact Direct psychological stress conditions like this often cause stress (NIOSH, 2008). Work stress is a phisical condition and emotional which is happened dangerously when work is not properly done with the skill, job resource and needs (NIOSH, 2008) National survey in french(Frasser, 1997) found that 74\% of nurses had work stress. The result research of Indonesian Nastional Care Union (2006) found 50,9\% indonesian nurses had work stress, which was caused by high work overload and waste time, low salary and unsufficient incentive (Muthmainah, 2012). The kind of research is descriptive non experimental research by using cross sectional study approach with 20 respondents sample of in patientward. The technique of sampling taken by using purposive sampling. The data is got from the questionary result and analyzed by univariate with frequency. The results showed that the majority of nurses (55\%) experienced work stress. From the results it can be concluded that there is work stress in the nurse's work environment in the inpatient room, it is expected that nurses can perform assertive ways in solving problems and also the hospital provides counseling media for nurses who experience work stress.

Key words: Nurse; Hospital; Inpatient Room; Work stress

Jurnal SMART Keperawatan Sekolah Tinggi Ilmu Kesehatan (STIKes) Karya Husada Semarang www.stikesyahoedsmg.ac.id/ojs/index.php/sjkp(perawat) 


\section{Pendahuluan}

Semua sumber daya termasuk sumber daya manusia dalam suatu organisasi keperawatan menurut fungsi manajemen diharapkan mampu memberikan tugas kepada staf sesuai dengan tanggung jawab dan kompetensinya, menentukan jalinan hubungan kerja antar staf dan menciptakan penugasan yang kondusif (Kurniadi, 2013). Tenaga keperawatan merupakan ujung tombak dalam memberikan pelayanan di rumah sakit karena perawat adalah provider yang selalu kontak selama 24 jam dengan pasien. Kondisi ini berdampak pada peran perawat yang juga mempengaruhi mutu pelayanan dirumah sakit. Peran perawat dalam memberikan pelayanan sering mengalami tekanan psikologi, hal ini bisa disebabkan karena beban kerja yang berlebihan, waktu pelaksanaan, kontak penyakit pasien secara langsung kondisi tekanan psikologi seperti ini sering menimbulkan stres (NIOSH, 2008).

Kondisi stres perawat Rawat Inap Instalasi Penyakit Dalam RSUP Dr M Djamil Padang relatif tinggi karena tingginya angka pasien rawat dibandingkan jumlah perawat yang ada. Nilai BOR rata-rata ruangan di Instalasi Penyakit Dalam adalah 80-80,2\% dengan perbandingan jumlah tempat tidur pasien dengan jumlah perawat adalah 3:1, hal ini berbeda dengan kondisi idealnya perbandingan jumlah tempat tidur pasien dengan jumlah perawat adalah 1:1, sehingga dari keadaan ini terlihat pekerjaan perawat overload. Kondisi lain yang memicu timbulnya stres kerja terutama diruang ruang rawat inap yaitu kondisi emosional keluarga pasien sering tidak stabil, perawat sering mendapatkan keluarga pasien marah karena tidak menerima kondisi keluarganya yang sedang kritis. Stres kerja yang dihadapi oleh perawat di Instalasi Penyakit Dalam biasanya mereka atasi dengan liburan bersama, melakukan tindakan rotasi perawat antar ruang rawat dalam satu instlasi, metode religi dan senam rutin setiap minggu. Kegiatan untuk menghadapi stres kerja ini hanya bersifat sementara dan rutinitas.

Stres kerja merupakan suatu kondisi fisik dan emosional yang berbahaya yang terjadi ketika pekerjaan yang dilakukan tidak sesuai dengan kemampuan, sumber daya dan kebutuhan pekerja (NIOSH, 2008). Menurut data Kementerian Kesehatan RI tahun 2014 jumlah perawat di Indonesia mencapai 237.181 orang, dengan demikian angka kejadian stres kerja pada perawat cukup besar (Kemenkes, 2014). 
Penelitian tentang stres kerja juga dilakukan oleh Zukhra (2012) yaitu stres kerja perawat ICU di RSUD Arifin Achmad Pekanbaru didapatkan hasil bahwa ada 4 tema analisis stres kerja pada perawat yaitu penyebab stres, gejala stres, waktu stres dan tingkatan stres. Penyebab stres kerja terdiri dari lingkungan kerja yang tidak kondutif, hubungan dengan atasan yang kurang harmonis, kerjasama tim yang kurang, pembagian jadwal dinas yang tidak sesuai, menghadapi kondisi darurat pasien, keluhan dari keluarga pasien, kurang memiliki kompetensi, catatan keperawatan yang banyak, melakukan pekerjaan non keperawatan, rasio perawat-pasien tidak sesuai, beban kerja yang lebih tinggi dan masalah pribadi (Zukra, 2012).

Stres kerja yang tinggi dapat menggangu kenormalan aktivitas kerja, menurunkan tingkat produktivitas, kepuasan kerja rendah dan kinerja menurun, semangat dan energi menjadi hilang, komunikasi tidak lancar, pengambilan keputusan jelek, kreativitas dan inovasi kurang, dan bergulat dengan tugas-tugas yang tidak produktif. Jadi, stres kerja yang terlalu tinggi dapat mempengaruhi kualitas individu maupun organisasi (Munandar, 2008).

Faktor penyebab stres kerja terdiri dari 3 sumber, yaitu faktor yang bersumber pada pekerjaan itu sendiri, bersumber pada organisasi tempat bekerja dan faktor eksternal diluar pekerjaannya seperti faktor lingkungan, keluarga, peristiwa krisis dalam kehidupan dan lainlain (Greenberg, 2012). Salah satu faktor yang bersumber pada pekerjaan diantaranya beban kerja. Beban kerja adalah beban fisik dan non fisik yang ditanggung oleh pekerja untuk menyelesaikan pekerjaan (Depkes RI, 2009).

Rumah Sakit Umum Pusat Dr M Djamil Padang merupakan rumah sakit pendidikan tipe A yang menjadi rujukan Propinsi Sumatera bagian tengah. Rumah Sakit Umum Pusat M Djamil Padang terdiri dari 800 tempat tidur yang berada di 27 instalasi. Berdasarkan study awal yang telah dilakukan pada 10 perawat di Instalasi Rawat Inap Penyakit Dalam Non Bedah RSUP M.Djamil Padang pada tanggal 10 April 2018 di dapatkan hasil kuesioner bahwa 6 perawat yang bekerja di ruangan tersebut mengeluhkan stres kerja berat, dan 4 perawat mengalami stres kerja ringan. Sedangkan pada beban kerja 7 perawat mengeluhkan beban kerja yang berat dan 3 perawat mengeluhkan beban kerja ringan. Saat di wawancarai dari 10 perawat 5 perawat mengeluhkan sering pusing, kelelahan, emosi yang tidak terkontrol, sulit 
berkonsentrasi dalam bekerja, merasakan kebosanan dan beban kerja yang begitu berat karena tuntutan pasien dan keluarga dengan diagnosa yang bermacam macam.

Stategi koping yang biasanya diterapkan masing-masing ruangan untuk mencegah stres kerja yang terjadi karena beban kerja yang tinggi yaitu memberikan jadwal dinas yang fleksibel serta melakukan liburan bersama setahun sekali, namun strategi yang digunakan ini kurang optimal karena bersifat sementara/sesaat. Menurut wawancara dengan Kabid Pelayanan Keperawatan RSUP DR M Djamil Padang kegiatan senam bersama setiap minggu dilakukan di lingkungan kerja pegawai rumah sakit. Senam bersama ini dilakukan sebagai salah satu upaya untuk media rekreasi bagi pegawai rumah sakit dari rutinitas pekerjaan. Banyak perawat yang tidak mengikuti kegiatan senam yang diadakan oleh pihak rumah sakit, hal ini terjadi karena waktu pekerjaan perawat yang bersifat shift, sehingga media rekreasi ini tidak merata dirasakan perawat dirumah sakit.

Dengan latar belakang diatas dan didukung dengan belum adanya penelitian tentang stres kerja perawat rawat inap di RSUP DR M Djamil Padang, hal tersebut menjadi perhatian peneliti melakukan penelitian tentang gambaran stres kerja perawat ruang rawat inap penyakit dalam di RSUP Dr M Djamil Padang.

\section{Tinjauan Teoritis}

\section{A. Stres Kerja}

Stres merupakan psychological and physical strain or tension generated by physical, emotional, social, economic, or occupational circumstances, events, or experiences that are difficult to manage or endure yakni stres psikologis dan fisik merupakan ketegangan yang disebabkan oleh fisik, emosi, sosial, ekonomi, pekerjaan atau keadaan, peristiwa, atau pengalaman yang sulit untuk mengelola atau bertahan (Colman, A, 2001 dalam Nasir \& Muthith, 2011). Stres diartikan sebagai ketidakmampuan mengatasi ancaman yang dihadapi oleh mental, fisik, emosional dan spritual manusia, yang suatu saat dapat mempengaruhi kesehatan fisik manusia (Cooper, 1994 dalam Perry \& Potter 2010). Jadi stres adalah suatu perasaan yang timbul akibat ragu ketidakmampuan mengatasi sesuatu.

Tiga penyebab stres dalam kehidupan adalah aktifitas sosial ; keluarga, pekerjaan, pendidikan, kesehatan,dan kehidupan masyarakat ; kehidupan sosial yakni bagaimana 
sesorang dalam pandangan lingkungannya ; keinginan yakni eksistensi, pertunangan dan pernikahan (Struart \& Laraia, 2013).Stres kerja adalah ketidakmampuan individu dalam memenuhi tuntutan-tuntutan pekerjaannya sehingga ia merasa tidak nyaman dan tidak senang (Saam \& Wahyuni, 2012). Stres kerja merupakan kombinasi antara sumber-sumber stres pada pekerjaan, karakteristik individual, dan stresor di luar organisasi (Greenberg, 2012). Jadi stres kerja adalah ketidakmampuan individu dalam memenuhi stimulus yang muncul dari dalam dan luar organisasi pekerjaan.

\section{B. Gejala Stres Kerja}

Stres dapat menghasilkan berbagai respon, respon stres dapat terlihat dalam berbagai aspek yaitu respon fisiologis, respon kognitif, respon emosi, respon tingkah laku (Taylor (1991) dalam Nasir \& Muhith 2011). Gejala fisiologis sebagai konsekuensi dari stres menunjukkan bahwa stres dapat menciptakan perubahan dalam metabolisme, meningkatkan detak jantung dan pernafasan, meningkatkan tekanan darah, menimbulkan sakit kepa dan menyebabkan serangan jantung. Gejala psikologis memicu timbulnya ketidakpuasan kerja, meningkatkan ketegangan, kecemasan, kebosanan, mudah marah dan suka menunda pekerjaan. Sedangkan gejala perilaku yaitu menurunnya tingkat produktivitas, meningkatkan absensi dan turn over karyawannya. Selain itu perubahan pada pola makan, cara bicara yang menjadi cepat, gelisah, gangguan tidur dan meningkatnya konsumsi rokok dan alkohol (Rice 1999, dalam Prihatini, 2008).

\section{Dampak Stres Kerja}

Dampak stres kerja dapat dirasakan dalam bentuk efek fisiologi bahkan sampai menimbulkan penyakit maupun efek psikologi yang dapat mempengaruhi perilaku seseorang dalam bekerja. Stres yang timbul akibat ketidakjelasan sasaran dalam pekerjaan akhirnya mengarah ketidakpuasan pekerjaan, kurang memiliki percaya diri, rasa tidak berguna, rasa harga diri yang menurun, depresi, motivasi rendah untuk bekerja, peningkatan tekanan darah dan detak nadi, dan kecendrungan untuk meninggalkan pekerjaan (Munandar, 2008). Pada umum stres kerja lebih banyak merugikan diri karyawan maupun perusahaan. Pada diri karyawan konsekuensi tersebut dapat berupa menurunnya gairah kerja, kecemasan yang tinggi, frustasi dan sebagainya (Rice, 1999 dalam Prihatini, 2008). 


\section{Instalasi Penyakit Dalam RSUP DR M Djamil Padang}

Rumah Sakit Umum Pusat (RSUP) M.Djamil Padang merupakan rumah sakit rujukan untuk wilayah Sumatra Bagian Tengah yang memiliki beberapa unit ruang rawat inap salah satunya ialah ruang rawat inap penyakit dalam non bedah. Nilai Bed Occupation Rate (BOR) adalah sekitar 80-80,2 \% dan ALOS adalah sekitar 2-3 hari. Perbandingan jumlah tempat tidur pasien dengan jumlah perawat tidak sesuai, dimana perbandingan jumlah tempat tidur pasien dengan jumlah perawat adalah 3:1.

\section{Metodologi Penelitian}

Penelitian ini merupakan Jenis penelitian deskriptif dengan pendekatan cross sectional study, jumlah sampel adalah 20 perawat ruang rawat inap Instalasi penyakit Dalam RSUP Dr M Djamil Padang. Teknik pengambilan sampel purposif sampling, dengan kriteria inklusi : bersedia menjadi responden dan tidak memiliki riwayat penyakit kronis, kriteria ekslusi : perawat cuti, izin dan sakit. Sebelum dilakukan penelitian peneliti telah melakukan uji etik penelitian dibagian komite etik penelitian RSUP Dr M Djamil Padang. Alat ukur penelitian ini menggunakan kuesioner baku dari hasil penelitian Dwijayanti (2010) yang berisi tentang Self report measure. Penelitian ini dilaksanakan di ruang rawat inap Dalam RSUP DR. M. Djamil Padang, pada bulan Mei 2018.

\section{Hasil Penelitian}

\section{Distribusi frekuensi Stres Kerja Perawat Ruang Rawat Inap \\ Tabel 4}

Distribusi Frekuensi Stres Kerja Perawat Ruang Rawat Inap RS M Djamil Padang Tahun 2018

\begin{tabular}{cccc}
\hline No & $\begin{array}{c}\text { Klasifikasi Stres } \\
\text { Kerja } \\
\text { Perawat Rawat } \\
\text { Inap }\end{array}$ & f & \% \\
\hline 1 & Stres Kerja & 11 & 55 \\
\hline 2 & Tidak Stres Kerja & 9 & 45 \\
& Jumlah & $\mathbf{2 0}$ & $\mathbf{1 0 0}$ \\
\hline
\end{tabular}

Berdasarkan table 4 di atas terlihat bahwa sebagian besar responden penelitian mengalami stres kerja yaitu 11 responden $(55 \%)$. 
Nilai Stres Kerja Perawat Ruang Rawat Inap

Tabel 5

Nilai Stres Kerja Perawat Rawat Inap Instalasi Penyakit Dalam Tahun 2018

\begin{tabular}{c|cccc}
\hline Ruangan & $\begin{array}{c}\text { Minim } \\
\text { um }\end{array}$ & $\begin{array}{c}\text { Maxi } \\
\text { mum }\end{array}$ & Mean & $\begin{array}{c}\text { Std. } \\
\text { Devia } \\
\text { tion }\end{array}$ \\
\hline $\begin{array}{c}\text { PERAWAT } \\
\text { RAWAT } \\
\text { INAP }\end{array}$ & 16 & 31 & 21,90 & 4,844 \\
\hline
\end{tabular}

Berdasarkan Tabel 5 perawat Rawat Inap RS M Djamil Padang nilai minimum stres kerja perawat yaitu 16 , nilai maksimum 31 , dan nilai stres kerja rata-rata yaitu 21,90, simpangan baku yaitu 4,844 .

\section{Pembahasan}

Rata-rata umur perawat yang bekerja diruang ruang rawat inap adalah dalam rentang usia 31 40 tahun. Menurut Siboro (2009) umur dewasa awal hingga dewasa tengah secara psikologis termasuk kelompok usia yang labil dan sukar beradaptasi dengan lingkungan kerja. Berbeda dengan kelompok umur dewasa akhir yang sudah sangat stabil dan mantab dalam pengambilan keputusan. Jadi perawat ruang rawat inap rata-rata berada pada usia dewasa awal dimana tingkat psikologis diusia tersebut masih labil dalam hal mengkoping permasalahan sehingga stres kerja rentan terjadi pada perawat.

Rata-rata perawat ruang rawat inap berjenis kelamin perempuan dengan persentase (100\%). Stres kerja yang dialami perawat laki-laki dan perempuan bisa saja berbeda hal tersebut dikarenakan secara fisik dan mental berbeda, serta respon terhadap stresor yang berbeda pula. Respon laki-laki terhadap stres lebih bersifat konstruktif sehingga menghasilkan kemampuan adaptasi yang baik dan tingkat stres kerja dipersepsikan ringan. Sedangkan perawat perempuan dalam menjalankan profesinya selain bertugas dirumah sakit juga memilki tuntunan peran dalam rumah tangga hal tersebut.

Stres ditentukan oleh individunya sendiri. Reaksi-reaksi psikologis, fisiologis, dan atau dalam bentuk perilaku terhadap stres adalah hasil interaksi situasi dengan individunya. Tuntutan peran ganda umumnya dialami perempuan yang melibatkan diri dalam lingkungan organisasi, yaitu sebagai wanita karir dan ibu rumah tangga sehingga lebih rentan mengalami stres. Tuntutan pekerjaan, rumah tangga dan ekonomi berpotensi wanita karir rentan mengalami stres (Anitawidanti, 2010). 
Rata-rata lama waktu kerja perawat ruang rawat inap adalah 4 tahun. Dari hasil tersebut diperoleh kesimpulan rata-rata lama bekerja ruang rawat inap Instalasi Penyakit Dalam lebih dari 3 tahun. Perawat yang lama bekerja lebih dari tiga tahun memiliki kecenderungan bosan terhadap rutinitas yang terus menerus. Gambaran ini sejalan dengan penelitian Siboro (2009) yang menyatakan bahwa semakin lama masa kerja seseorang maka semain stres didalam pekerjaannya. Hal ini dapat terjadi karena pegawai yang sudah mempunyai masa kerja yang lama dapat menimbulkan kebosanan dalam bekerja atau merasakan kerja yang monoton dalam waktu yang lama.

Menurut hasil penelitian didapatkan bahwa perawat Rawat Inap RS M Djamil Padang nilai minimum stres kerja perawat yaitu 16, nilai maksimum 31, dan nilai stres kerja rata-rata yaitu 21,90 artinya stres kerja perawat di ruang rawat inap Instalasi Penyakit Dalam RSUP Dr M Djamil Padang dengan klasifikasi sebagai berikut perawat yang mengalami stres kerja 55\% dan yang tidak mengalami stres kerja 45\%. Hasil ini menunjukkan adanya stres kerja perawat dilingkungan kerja RSUP Dr M Djamil Padang. Hasil analisa ini sejalan wawancara peneliti bersama Karu HCU Instalasi Penyakit Dalam RSUP M Djamil, jumlah perawat tidak sesuai dengan kebutuhan tenaga karena jumlah tempat tidur diruang rawat inap lebih banyak yaitu mencapai 3:1. Perbandingan jumlah perawat dengan jumlah pasien yang tidak sudah seimbang ini menyebabkan terjadi overload pekerjaan gejala stres yang dirasa ketika situasi kerja mulai terasa tegang adalah gejala fisik seperti nadi cepat, tegang otot dan nyeri kaki.

Gejala stres yang dihadapi perawat terdiri dari 3 yaitu gejala fisik, gejala psikologis, dan gejala perilaku. Menurut Muthmainah (2012), gejala fisiologi akibat stres menciptakan perubahan dalam metabolisme, meningkatkan detak jantung dan pernafasan, meningkatkan tekanan darah, dan menimbulkan sakit kepala. Gejala psikologis muncul akibat tidak efektifnya koping memicu timbulnya ketidakpuasan kerja, meningkatkan ketegangan, kecemasan, kebosanan, mudah marah dan suka menunda pekerjaan. Sementara itu menurut Mojoyinola (2008) dalam penelitiannya menyatakan bahwa terdapat perbedaan yang signifikan dalam pribadi dan perilaku perawat yang mengalami stres kerja yakni menurunnya produktivitas, pola makan, cara bicara dan gangguan tidur.

Penyebab stres kerja yang sering terjadi pada petugas kesehatan meliputi kerja shift jam kerja yang panjang, peran yang amabigu, konflik peran, terpaparnya petugas kesehatan terhadap 
infeksi dan substansi bahaya timbulnya yang ada dirumah sakit. Beberapa penelitian tentang stres kerja terhadap perawat juga telah dilakukan berhubungan dengan beban kerja yang berlebih (work overload), tuntutan waktu pengerjaan tugas yang cepat, tidak adanya dukungan sosial dalam bekerja (khususnya dari supervisor. Kepala perawat dan managerial keperawatan yang lebih tinggi), terpaparnya penyakit infeksi, tertusuk jarum dan berhubungan dengan pasien sulit atau kondisi sulit pasien yang serius (NIOSH, 2008).

Menurut analisa peneliti berdasarkan hasil kuesioner bahwa rata-rata gejala stres kerja yang dialami perawat ruang rawat inap banyak dari gejala psikologis $(45 \%)$, oleh karena itu kondisi stres kerja perawat ruang rawat inap ini dapat diselesaikan dengan strategi koping perawat yang tepat agar menekan terjadinya stres kerja bagi perawat dengan pekerjaan yang monoton dan penuh tekanan.

\section{Kesimpulan}

Berdasarkan hasil penelitian dapat disimpulkan bahwa : Perawat ruang rawat inap Instalasi Penyakit Dalam RSUP Dr M Djamil Padang sebagian besar perawat berada pada klasifikasi mengalami stres kerja.

\section{Saran}

Pihak rumah sakit perlu menyediakan media konseling sebagai tempat konsultasi bagi perawat yang sedang mengalami masalah dengan melibatkan staf ahli keperawatan jiwa. Memberikan pelatihan CLMHN yang bersifat psikologis agar perawat lebih siap menghadapi dan mengatasi stres kerja serta mengadakan follow-up dari setiap hasil evaluasi tentang kondisi psikologis perawat melalui angket atau kuesioner secara periodik.

\section{Daftar Pustaka}

Anitawidanti, H. (2010), Analisis hubungan antara stres kerja dengan kepuasan kerja karyawan berdasarkan gender studi pada PT Transindo Surya Sarana Semarang. Skripsi. Http://eprints.undip.ac.id . Diunduh : 21 Agustus 2017

Departemen Kesehatan RI. (2009). Standar kesehatan dan keselamatan kerja di rumah sakit $(K 3 R S)$. Jakarta : Depkes RI

Depkes, RI, (2009). Standar kesehatan dan keselamatan Rumah sakit (K3RS). Jakarta : Depkes RI

Gillies, D.A. (2009). Manajemen keperawatan, suatu pendekatan system edisi kedua (Dika Sukaman dan Widya Sukaman penerjemah). Philadeplhia : W.B. Saunders Company 
Greenberg, J.S. (2012). Comprehensive Stress Management (8th Ed). New York : Mc. Graw Hill

Kurniadi, A. (2013). Manajemen Keperawatan dan Prospektifnya Teori, Konsep, dan Aplikasi. Edisi 1. Jakarta : FKUI

Majoyinola, J.K.(2008). Effecy of Job Stress Helath, Personal and Work Berhaviour of Nurses in Public Hospital in Ibadan Metropolis, Nigeria. Ethno-Med journal; 143-144

Munandar, A.S. (2008). Psikologi Industri dan Organisasi. Jakarta :UI-Press

Muthmainah, I. (2012). Faktor-faktor Penyebab Stres Kerja di Ruangan ICU Pelayanan Jantung Terpadu Dr.Cipto Mangunkusumo Jakarta.Skripsi. Fakultas Ilmu Keperawatan. Jakarta

Nasir \& Muhith. (2011). Dasar-dasar keperawatan jiwa. Jakarta : Salemba Medika

NIOSH. (2008). Exposure to Stress Occupational Hazard. NIOSH

Perry \& Potter. (2010). Fundamental Keperawatan. Edisi : 4. Jakarta: EGC

Prihatini. (2008). Analisis hubungan beban kerja dengan stres kerja perawat di Ruang rawat inap RSUD Sidikalang. http://repository.usu.ac.id/bitstream/123456789/6899/1/08E00192.pdf. Diunduh : 2 Maret 2017

Profil Kesehatan Indonesia 2014. Jakarta: Kementerian Kesehatan Republik Indonesia; 2014Saam dan Wahyuni. 2012. Psikologi Keperawatan. Jakarta : RajaGrafindo Persada

Siboro, T.S. (2009). Hubungan kondisi kerja dan karakteristik individu dengan stres kerja pada pegawai lembaga pemasyarakatan kelas IIB lubuk pakam 2008. Tesis. Fakultas Ilmu Keperawatan Universitas Sumatera Utara. http://repository.usus.ac.id, diunduh 20 Agustus 2017

Stuart \& Laraia. (2013). Principles and practice of psychiatric Nursing. Jakarta: EGC

Swanburg, R.C. (2010). Pengantar Kepemimpinan dan Manajemen Keperawatan. Terjemahan. Jakarta: EGC

Zukhra. (2012). Stres kerja perawat ICU RS Achmad Arifin Pekanbaru. USU : Indonesian Nursing Research Jounal, 2013 